\title{
PEMBENTUKAN PERATURAN DESA (PERDES): TINJAUAN HUBUNGAN KEWENANGAN KEPALA DESA DAN BADAN PERMUSYAWARATAN DESA (BPD)
}

\author{
Elviandri \\ Universitas Muhammadiyah Riau, Indonesia, elviandri@umri.ac.id \\ Indra Perdana \\ Universitas Muhammadiyah Riau, Indonesia, indraperdana@gmail.com
}

\begin{abstract}
This journal focuses on the problem of finding the relationship between the role of the Headman of Village and the Village Consultative Body (BPD) in drafting Village Regulations (Perdes). The journal research method used is the normative method. The results of the study carried out are the relationship between the authority of the Village Head and the Village Consultative Body (BPD). . As for the process of drafting and forming Aursati Village regulations in the preparation of village regulations carried out by the Village Consultative Body (BPD) with the Aursati Village Head, the drafting process uses the correct mechanism and all stages are passed well
\end{abstract}

Keyword: Village Regulations, Headmen of Village, Village Consultative Body

\begin{abstract}
Abstrak
Jurnal ini memfokuskan permasalahan dalam mencari hubungan peran Kepala Desa dan Badan Permusyawaratan Desa (BPD) dalam menyusun Peraturan Desa (Perdes). Metode penelitian jurnal yang digunakan adalah metode normatif. Hasil dari kajian yang dilakukan adalah adanya hubungan kewenangan Kepala Desa dengan Badan Permusyawaratan Desa (BPD) Dalam Pembentukan Peraturan Desa Aursati dapat disimpulkan bahwa, Pola hubungan Kewanangan antara Badan Permusyawaratan Desa (BPD) dan Kepala Desa adalah dalam bentuk hubungan kemitraan, konsultasi, dan koordinasi. Adapun proses penyusunan dan pembentukan peraturan Desa Aursati dalam penyusunan peraturan desa yang dilakukan oleh Badan Permusyawaratan Desa (BPD) dengan Kepala Desa Aursati, proses penyusunannya menggunakan mekanisme yang benar dan semua tahap dilalui dengan baik
\end{abstract}

Kata Kunci: Peraturan Desa, Kepala Desa, Badan Permusyarawatan Daerah

\section{A. Pendahuluan}

Pemerintah Desa memiliki peran yang sangat signifikan dalam pengelolaan proses sosial di dalam masyarakat. Tugas utama yang harus diemban Pemerintah Desa adalah bagaimana menciptakan kehidupan demokratis, dan memberikan pelayanan sosial yang baik, sehingga dapat 
membawa warganya pada kehidupan yang sejahtera, tentram, aman dan berkeadilan. ${ }^{1}$ Untuk menghindari salah pengertian, yang dimaksud memiliki status dan kedudukan seperti Provinsi, kabupaten, atau kota, adalah status dan kedudukan hukum.

Penyelenggaraan pemerintahan desa merupakan subsistem dari sistem penyelenggaraan pemerintahan, sehingga desa memiliki kewenangan untuk mengatur dan mengurus kepentingan masyarakatnya. Desa dapat melakukan perbuatan hukum, baik hukum publik maupun hukum privat, memiliki kekayaan, harta benda dan bangunan serta dapat dituntut dan menuntut di pengadilan. Untuk itu, kepala desa dengan persetujuan Badan Permusyawaratan Desa mempunyai wewenang untuk melakukan perbuatan hukum dan mengadakan perjanjian yang saling menguntungkan.

Peran BPD dengan fungsi dan wewenangnya dalam membahas rancangan serta menetapkan Peraturan Desa bersama Kepala Desa merupakan sebagai kerangka kebijakan dan hukum bagi penyelenggaraan pemerintahan dan pembangunan Desa. Penyusunan peraturan Desa merupakan penjabaran atas berbagai

\footnotetext{
1 M. Firmanhadi, Hubungan Fungsional Antara Pemerintah Desa dengan BPD dalam Menjalankan Pelaksanaan Pemerintahan Desa Berdasarkan Undang-Undang Nomor 32 Tahun 2004 tentang Pemerintahan Daerah, Jurnal Ilmiah Fakultas Hukum Universitas Mataram, 2013, hlm. 1.
}

kewenangan yang dimiliki Desa, tentu berdasarkan kepada kebutuhan dan kondisi Desa setempat, serta mengacu pada peraturan perundang-undangan yang lebih tinggi. Sebagai sebuah produk hukum, peraturan Desa tidak boleh bertentangan dengan peraturan yang lebih tinggi dan tidak boleh merugikan kepentingan umum. Sebagai sebuah produk politik, peraturan Desa disusun secara demokratis dan partisifatif, yakni proses penyusunannya melibatkan partisipasi masyarakat. Masyarakat mempunyai hak untuk mengusulkan atau memberi masukan kepada BPD maupun Kepala Desa dalam proses penyusunan peraturan desa. ${ }^{2}$

Dalam proses pengambilan keputusan di desa dilakukan dengan dua macam keputusan. Pertama, keputusan keputusan yang beraspek sosial, yang mengikat masyarakat secara sukarela, tanpa sanksi yang jelas. Kedua, keputusankeputusan yang dibuat oleh lembaga-lembaga formal desa yang dibentuk untuk melakukan fungsi pengambilan keputusan. Bentuk keputusan pertama, banyak dijumpai dalam kehidupan sosial masyarakat desa, proses pengambilan keputusan dilakukan melalui proses persetujuan bersama, dimana sebelumnya alasan-alasanuntuk pemilihan

2 E.B. Sitorus, dkk, Naskah Akademik Rancangan Undang-Undang tentang Pemerintahan Desa, DEPDAGRI, Jakarta, 2007, hlm. 7. 
alternatif diuraikan terlebih dahulu oleh para tetua desa ataupun orang yang dianggap memiliki kewibawaan tertentu. ${ }^{3}$

Adapun pada bentuk kedua, keputusan-keputusan didasarkan pada prosedur yang telah disepakati bersama, seperti proses Musyawarah Pembangunan Desa (Musbangdes) yang dilakukan setiap setahun sekali di balai desa. Proses pengambilan keputusan tersebut dilakukan oleh pihak-pihak secara hukum memang diberi fungsi untuk itu, yang kemudian disebut dengan Peraturan Desa (Perdes). Peraturan Desa adalah produk hukum tingkat desa yang ditetapkan oleh Kepala Desa bersama Badan Permusyawaratan Desa dalam rangka penyelenggaraan pemerintahan desa. Peraturan desa merupakan penjabaran lebih lanjut dari peraturan perundang-undangan yang lebih tinggi dengan memperhatikan kondisi sosial budaya masyarakat desa setempat. Peraturan Desa adalah produk hukum tingkat desa yang ditetapkan oleh Kepala Desa bersama Badan Permusyawaratan Desa dalam rangka penyelenggaraan pemerintahan desa. Peraturan desa merupakan penjabaran lebih lanjut dari peraturan perundangundangan yang lebih tinggi dengan memperhatikan kondisi sosial budaya masyarakat desa setempat.

3 Kushandajani, Otonomi Desa Berbasis Modal Sosial Dalam Perspektif Socio Legal, (Jurusan Ilmu Pemerintahan Fisip UNDIP, Semarang, 2008), hlm.70-71.
Badan Perwakilan Desa (BPD) yang ada selama ini berubah namanya menjadi Badan Permusyawaratan Desa, perubahan ini didasarkan pada kondisi faktual bahwa budaya politik lokal yang berbasis pada filosofi "musyawarahuntuk mufakat". Musyawarah berbicara tentang proses, sedangkan mufakat berbicara tentang hasil. Hasil yang baik diharapkan diperoleh dari proses yang baik. Melalui musyawarah untuk mufakat, berbagai konflik antara para elit politik dapat segera diselesaikan secara arif, sehingga tidak sampai menimbulkan goncangan-goncangan yang merugikan masyarakat luas. Namun dengan demikian terkadang apa yang telah disepakati oleh pemerintah desa dengan BPD tidak sesuai apa yang di inginkan oleh masyarakat. Kurangnya sosialisasi peraturan yang di buat oleh perangkat desa dengan BPD yang menjadi permasalahan yang dalam proses penyusunan dan penetapan peraturan tidak sesuai apa yang diinginkan masyarakat sehingga masih banyak yang melanggar peraturan desa.

\section{Rumusan Masalah}

Berdasarkan latar belakang diatas itu penyusun merasa tetarik untuk meneliti

1) Bagaimana proses BPD dalam penyusunan dan penetapan peraturan desa di Desa Aursati ?

2) Bagaimana proses BPD dalam penyusunan dan penetapan peraturan 
desa, berjalan secara

konferensif/menyeluruh ?

\section{B. Hasil Penelitian dan Pembahasan}

\section{Peraturan Desa}

Dalam Undang-undang Nomor 32 Tahun 2004 tentang Pemerintah Daerah, mengatur bahwa desa mempunyai wewenang mengatur dan mengurus masyarakat setempat sesuai dengan asal usul dan adat istiadat setempat. Dalam rangka mengatur dan urusan masyarakat tersebut pemerintahan desa dapat membuat Peraturan Desa.

Peraturaan desa adalah bentuk regulasi yang dikeluarkan Pemerintah Desa yang ditetapkan oleh Kepala Desa bersama Badan Permusyawaran Desa (BPD) sebagai bentuk penjabaran lebih lanjut dari peraturan perundang-undangan yang lebih tinggi dengan memperhatiakn kondisi sosial budaya masyarakat desa setempat.

Peraturan desa dibentuk dalam rangka penyelenggaraan pemerintahan desa, dengan demikian maka pemerintahan desa harus merupakan penjabaran lebih lanjut dari peraturan perundang-undangan yang lebih tinggi dan tidak boleh bertentangan dengan kepentingan umum dan atau peraturan perundang-undangan yang lebih tinggi serta harus memperhatikan kondisi sosial budaya masyarakat desa setempat dalam upaya mencapai tujuan pemerintahan, pembangunan dan pelayanan masyarakat jangka panjang, menengah dan jangka pendek. Peraturan desa yang dibuat hendaknya mempertimbangkan kebutuhan dan kemampuan masyarakat untuk melaksanakannya, maka dari itu peraturan desa haruslah benar-benar memperhatikan aspirasi masyarakat.

Pemberlakuan Undang-undang tentang Pemerintahan Daerah yang baru melalui Undang-Undang Nomor 32 Tahun 2004 tentang Pemerintahan Daerah tetap mengakui dan menguatkan Peraturan Desa. Definisi ini juga yang digunakan oleh Peraturan Pemerintah Nomor 72 Tahun 2005 yang merupakan pengaturan lebih lanjut tentang Desa. Dalam Undang-undang tentang pembentukan Peraturan Perundangundangan yang baru pada pasal 7 ayat (1) Undang-Undang Nomor 12 Tahun 2011 Peraturan Desa dikeluarkan dari hierarkhi peraturan perundangundangan, tetapi tetap diakui keberadaannya yang tertuang di pasal 8 ayat (1) Undang-undang Nomor 12 tahun 2011. Yang keberadaanya diakui dan mempunyai kekuatan hukum mengikat sepanjang diperintahkan oleh peraturan perundang-undangan yang lebih tinggi atau dibentuk berdasarkan kewenangan. Peraturan desa ditetapkan oleh Kepala Desa bersama Badan Permusyawaratan Desa. Peraturan desa 
dibentuk

dalam

rangka

penyelenggaraan pemerintahan desa yang merupakan penjabaran lebih lanjut dari peraturan perundang-undangan yang lebih tinggi dengan memperhatikan kondisi sosial budaya masyarakat desa setempat.

Tingkat kepentingan dalam penyusunan Peraturan desa ini hendaklah dilihat dari kerangka kepentingan sebagian besar masyrakat setempat agar peraturan desa tersebut dapat benar benar mewakili aspirasi masyarakat. Dalam hal ini masyarakat berhak memberikan masukan secara lisan atau tertulis dalam rangka penyiapan atau pembahasan rancangan peraturan desa dan peraturan desa dilarang bertentangan dengan kepentingan umum dan atau peraturan perundang-undangan yang lebih tinggi.

\section{Kewenangan Kepala Desa dalam Pembentukan Perdes}

Berdasarkan Undang-Undang Nomor 6 Tahun 2014 tentang Desa Pemerintahan Desa atau dalam bentuk nama lain seperti halnya Pemerintahan Wanua, keberadaannya adalah berhadapan langsung dengan masyarakat, sebagai ujung tombak pemerintahan yang terdepan. Pelaksanaan otonomisasi desa yang bercirikan pelayanan yang baik adalah dapat memberikan kepuasan bagi masyarakat yang memerlukan karena cepat, mudah, tepat dan dengan biaya yang terjangkau, oleh karena itu pelaksanaan di lapangan harus didukung oleh faktorfaktor yang terlibat dalam implementasi kebijakan tentang Desa tersebut. ${ }^{4}$

Pemerintahan Desa adalah penyelenggaraan urusan Pemerintahan dan Kepentingan masyarakat Setempat dalam sistem Pemerintahan Negara Kesatuan Republik Indonesia. Pemerintahan Desa merupakan bagian dari pemerintahan Nasional yang penyelenggaraannya ditujukan pada pedesaan. Pemerintahan Desa adalah suatu proses dimana usahausaha masyarakat desa yang bersangkutan dipadukan dengan usaha-usaha pemerintah untuk meningkatkan taraf hidup masyarakat.

Menurut ketentuan umum Pasal 1 Angka 3 Undang-Undang Nomor 6 Tahun 2014 tentang Desa Pemerintah Desa adalah Kepala Desa atau yang disebut dengan nama lain dibantu perangkat Desa sebagai unsur penyelenggara Pemerintahan Desa. Sedangkan Pemerintah Desa adalah Kepala Desa atau yang disebut dengan nama lain dibantu perangkat Desa sebagai unsur penyelenggara Pemerintahan Desa.

${ }^{4}$ Stewar Awaeh, Johannis E. Kaawoan, dan Josef Kairupan, Peranan Badan Permusyawaratan Desa (BPD) Dalam Penyelenggaraan Pengawasan Pemerintahan (Studi di Desa Sereh 1 Kecamatan Lirung Kabupaten Talaud), Jurnal Eksekutif, Vol 1, No 1 (2017), hlm. 5-6 
Dan pemeritahan Desa adalah Pemerintahan Desa adalah penyelenggaraan urusan pemerintahan dan kepentingan masyarakat setempat dalam sistem pemerintahan Negara Kesatuan Republik Indonesia. ${ }^{5}$

Berdasarkan pasal 14 ayat (2) butir () huruf b Peraturan Pemerintah Nomor 72 tahun 2005 tentang Desa, Peraturan Menteri Dalam Negeri Nomor 29 tahun 2006 tentang Pedoman Pembentukan dan Mekanisme Penyusunan Peraturan Desa dan Peraturan yang berkaitan dengan hal ini maka Kepala Desa mempunyai peranan penting dalam pembangunan dan perkembangan dan kemajuan Desa yang kemudian disempurnakan dalam Undangundang desa.

Kepala Desa Pasal 26; (1) Kepala Desa bertugas menyelenggarakan Pemerintahan Desa, melaksanakan Pembangunan Desa, pembinaan kemasyarakatan Desa, dan pemberdayaan masyarakat Desa. (2) Dalam melaksanakan tugas sebagaimana dimaksud pada ayat (1), Kepala Desa berwenang:

a. memimpin penyelenggaraan Pemerintahan Desa;

b. mengangkat dan memberhentikan perangkat Desa;

c. memegang kekuasaan pengelolaan Keuangan dan Aset Desa;

d. menetapkan Peraturan Desa;

e. menetapkan Anggaran Pendapatan dan Belanja Desa; f. membina kehidupan masyarakat Desa;

g. membina ketenteraman dan ketertiban masyarakat Desa;

b. membina dan meningkatkan perekonomian Desa serta mengintegrasikannya agar mencapai perekonomian skala produktif untuk sebesar-besarnya kemakmuran masyarakat Desa;

a. mengembangkan sumber pendapatan Desa;

b. mengusulkan dan menerima pelimpahan sebagian kekayaan negara guna meningkatkan kesejahteraan masyarakat Desa;

c. mengembangkan kehidupan sosial budaya masyarakat Desa;

d. memanfaatkan teknologi tepat guna;

e. mengoordinasikan Pembangunan Desa secara partisipatif;

f. mewakili Desa di dalam dan di luar pengadilan atau menunjuk kuasa hukum untuk mewakilinya sesuai dengan ketentuan peraturan perundang-undangan; dan

g. melaksanakan wewenang lain yang sesuai dengan ketentuan peraturan perundang-undangan.

Dalam menajalankan Pemerintahan Desa yang sangat sulit adalah membentuk suatu tatanan masyarakat yang dasar akan hukum. Kepala desa mempunyai tugas berat dalam membentuk suatu tatanan masyarakat yang sadar akan hukum salah satunya partisipasi dalam melibatkan diri membuat suatu produk hukum dalam desa yang dia pimpinnya (Perdes) dituangkan dalam Rancangan Peraturan Desa. Kepala Desa harus selalu mengutamakan kepentingan masyarkat desa. Kepala desa dan sfat kepala membuat peraturan desa 
yakni peraturan mengenai Anggaran Belanja Desa, ini merupakan sifatnya diharuskan setiap akhir tahunnya untuk mengetahui dan sebagai dasar untuk melakukan pembelanjaan keuangan desa untuk tahun berikutnya.

Kepala Desa mempunyai kewenangan untuk mengajukan Rancangan Peraturan Desa. Dalam melaksanakan kewenangan kepala desa mengajukan peraturan desa dengan mempertimbangkan aspirasi dan pertisipasi masyarkat desa. Kepala desa bermitra dengan Lembaga Pemberdayaan Masyarakat (LPM) lembaga inilah yang menampung aspirasi masyarakat, sebelum sampai ke kepala desa. Lembaga Pemberdayaan Masyarakat mengadakan atau menjalankan tugasnya dengan cara mengadakan Musyawarah Rencana Pembangunan Desa (Musrembangdes) ditingkat RT, dari hasil Musyawarah Rencanaan Pembangunan Desa tingkat RT ini dibawa ke Musyawarah Rencana Pembangunan Desa tingkat Dusun dan hasil Musrembangdes tingkat dusun ini baru mengadakan musyawarah Rencana Pembangunan Desa tingkat desa.

Musyawarah tingkat desa inilah untuk membahas keluhan, saran, masukan dan hal-hal ain yang berhasil dihimpunan dari masyarkat melalui Musrembangdes tingkat RT dan Musrembangdes tingkat Dusun untuk merencanakan dan merumuskan suatu Peraturan Desa. Rancangan peraturan desa digodok bersama kepala desa dan Badan Permusyawaratan Desa (BPD). Sehingga peranan Kepala Desa dalam mengajukan Peraturan Desa sangatlah penting duntuk meningkatkan sumberdaya manusia dan dapat memenuhi aspirasi masyarakat serta dapat membangun desa kearah yang lebih mandiir dan Otonomi sesuai yang diharapkan oleh Negara Kesatuan Republik Indonesia.

\section{Kewenangan BPD dalam Pembentukan Perdes}

Sesuai dengan peraturan Perundangundangan yang baru Undang-Undang Republik Indonesia Nomor 6 Tahun 2014 Tentang Desa bahwa Badan Permusyawaratan Desa berkedudukan sebagai salah satu unsur penyelenggara Pemerintah Desa. Kedudukan ini adalah untuk memperkuat pemerintah desa dalam melaksanakan hak untuk mengatur dan mengurus rumah tangganya sendiri secara demokratis sesuai dengan aspirasi masyarakat. Fungsi, dan Wewenang Badan Permusyawaratan Desa Dalam melaksanakan tugasnya, Badan Permusyawaratan Desa mempunyai fungsi sebagai berikut: ${ }^{6}$

6 Pasal 55 Badan Permusyawaratan Desa mempunyai fungsi: 
1) Fungsi Legislasi, Fungsi legislasi yang dilakukan oleh BPD Aursati mengacu kepada peraturan yang ada bahwa BPD berfungsi menetapkan Peraturan Desa bersama Kepala Desa serta BPD berfungsi menampung dan menyalurkan aspirasi masyarakat. Bersama dengan Kepala Desa, BPD merumuskan dan menetapkan peraturan desa.

2) Fungsi Pengawasan, pengawasan terhadap pelaksanaan pemerintahan merupakan salah satu alasan terpenting mengapa BPD perlu dibentuk. Pengawasan oleh BPD terhadap pelaksanaan pemerintahan desa Karamatwangi yang dipimpin Kepala Desa merupakan tugas BPD. Upaya pengawasan dimaksudkan untuk mengurangi adanya penyelewengan atas kewenangan dan keuangan desa dalam penyelenggaraan pemerintahan desa.

3) Fungsi Aspirasi, fungsi aspirasi ini merupakan penyampaian aspirasi oleh warga kepada BPD tidak jarang pula dilakukan baik secara individu

\footnotetext{
a.membahas dan menyepakati Rancangan Peraturan Desa bersama Kepala Desa;

b.menampung dan menyalurkan aspirasi masyarakat Desa; dan

c.melakukan pengawasan kinerja Kepala Desa.

Undang-Undang Republik Indonesia Nomor 6 Tahun 2014 Tentang Desa
}

maupun bersama-sama dengan
menyampaikan langsung kepada
anggota BPD yang ada di
lingkungannya (RW).

Dengan demikian yang menjadi wewenang Badan Permusyawaratan Desa adalah :

1) Membahas rancangan Peraturan Desa bersama Kepala Desa;

2) Melaksanakan pengawasan terhadap pelaksanaan Peraturan Desa dan Peraturan Kepala Desa;

3) Mengusulkan pengangkatan dan pemberhentian Kepala Desa;

4) Membentuk panitia Pemilihan Kepala Desa;

5) Menggali, menampung, menghimpun, merumuskan dan menyalurkan aspirasi masyarakat;dan

6) Menyusun Tata Tertib Badan Permusyawaratan Desa

Hubungan yang bersifat kemitraan antara BPD dengan Pemerintah Desa harus Didasari pada filosofi antara lain: ${ }^{7}$

1) Adanya kedudukan yang sejajar diantara yang bermitra ;

2) Adanya kepentingan bersama yang ingin dicapai ;

3) Adanya prinsip saling menghormati.

7 Wasistiono, Sadu. 2006. Prospek Pengembangan Desa. CV. Bandung. Fokusmedia., hlm. 26. 
4) Adanya niat baik untuk membantu dan saling mengingatkan.

\section{Hubungan Kewenangan Kepala Desa dan BPD dalam Pembentukan Perdes}

Hubungan Kewenangan Kepala Desa dan BPD dalam Pembentukan Perdes pada penelitian ini merupakan suatu hubungan yang dilakukan oleh Badan Permusyawaratan Desa (BPD) dengan Kepala Desa khususnya dalam menyusun Peraturan Desa. Badan Permusyawaratan Desa (BPD) dengan Kepala Desa secara hukum memiliki hubungan kewenangan sebagai mitra kerja dan diwajibkan untuk bekerja sama sesuai dengan tugas dan wewenang masing-masing dalam membuat peraturan desa.

Tugas dan wewenang Kepala Desa dalam proses penyusunan Peraturan Desa Untuk membuat sebuah Peraturan Desa, hal utama yang harus dilakukan oleh Kepala Desa yaitu menyusun rancangan Peraturan Desa tersebut, dalam hal ini mengenai Anggaran Pendapatan dan Belanja Desa (APBDes). Sehingga Kepala Desa pertama-tama menyusun draf rancangan. Dalam menyusun draf rancangan Anggaran Pendapatan dan Belanja Desa (APBDes) ini, Kepala Desa melakukan rapat dengan Pemerintah Desa terlebih dahulu sebelum nantinya akan diajukan kepada Ketua Badan Permusyawaratan Desa (BPD) Aursati.
Setelah melakukan perancangan penyusunan draf peraturan desa, maka Kepala Desa kemudian mengajukan draf rancangan peraturan desa kepada Ketua Badan Permusyawaratan Desa (BPD) untuk mendapat persetujuan ataupun mendapat masukan atau kritikan mengenai draf tersebut.

Setelah menyusun dan mengajukan draf rancangan peraturan desa kepada Ketua Badan Permusyawaratan Desa (BPD) untuk mendapatkan persetujuan. Kemudian peraturan desa tersebut ditetapkan oleh Ketua Badan Permusyawaratan Desa (BPD) dan Kepala Desa. Ini sesuai dalam Peraturan Pemerintah Nomor 72 tahun 2005 pasal 14 bahwa tugas dan wewenang Kepala Desa setelah Kepala Desa melakukan penyusunan rancangan peraturan desa dan pengajuan rancangan peraturan desa kepada Badan Permusyawaratan Desa (BPD) adalah menetapkan rancangan peraturan desa menjadi peraturan desa bersama-sama dengan Badan Permusyawaratan Desa (BPD).

Adapun Tugas dan wewenang Badan Permusyawaratan Desa (BPD) dalam proses penyusunan Peraturan Desa Tugas dan wewenang Ketua Badan Permusyawaratan Desa (BPD) dalam hal penyusunan peraturan desa adalah menetapkan peraturan desa yang telah disusun dan diajukan oleh Kepala Desa. 
Ketua Badan Permusyawaratan Desa (BPD) juga diberikan wewenang pula oleh Kepala Desa untuk mengoreksi kembali draf rancangan peraturan desa sebelum dibuat atau ditetapkan. Sehingga Badan Permusyawaratan Desa (BPD) juga dapat memberikan masukan atau kritikan mengenai draf rancangan peraturan desa tersebut.

Peraturan Desa yang dihasilkan pada tahun 2018 dan 2019 oleh Badan Permusyawaratan Desa (BPD) dalam kemitraannya dengan Kepala Desa Kepala Desa dan Badan Permusyawaratan Desa (BPD) Aursati membuat Peraturan Desa yaitu :

1) Peraturan Desa Aursati Nomor: 007 Tahun 2018 Tentang Perubahan Anggaran Pendapatan dan Belanja Desa (APBDes-P);

2) Peraturan Desa Aursati Nomor: 001 Tahun 2019 Tentang Laporan Pertanggung Jawaban Realisasi Pelaksanaan APBDes Tahun Anggaran 2018.

Kualitas peraturan desa di Kabupaten Gresik dapat dilihat dari indikator atau parameter penilaian, yang menjadi obyek penelitian adalah Peraturan Desa Aursati Nomor: 007 Tahun 2018 Tentang Perubahan Anggaran Pendapatan dan Belanja Desa (APBDes-P) dan Peraturan Desa Aursati Nomor: 001 Tahun 2019 Tentang
Laporan Pertanggung Jawaban Realisasi Pelaksanaan APBDes Tahun Anggaran 2018.

1. Strategi yang dapat dilakukan dalam membentuk Peraturan Desa Aursati yang berkualitas

Strategi dalam membentuk peraturan desa dapat ditemukan dan digali melalui pelaksanaan Peraturan Desa Aursati dalam menggali hambatan pembentukan peraturan desa dan upaya yang dilakukan oleh pemerintah desa selama ini dalam mengatasi hambatan tersebut. Berdasarkan hasil penelitian Penulis terdapat hambatan, upaya yang Penulis himpun, termasuk strategi yang berhasi Penulis rumuskan, sebagai berikut:

a. Pengetahuan hukum

Pemerintah desa kurang dalam pengetahuan hukum, baik karena kualifikasi pendidikan, kurang mencari informasi, atau kurangnya kesadaran hukum. Upaya yang dilakukan oleh Pemerintah desa yakni konsultasi kepada Bagian Hukum Pemerintah Kabupaten Kampar, dan mengambil peraturan desa dari desa lain sebagai referensi. Tetapi, pelaksanaan upaya tersebut tidak semua menjadi positif bagi 
pemerintah desa, melainkan beberapa desa melakukan copy paste kepada peraturan desa dari desa yang lain.

Strategi dalam mengatasi hambatan tersebut melalui peran dari Bagian Hukum Pemerintah Kabupaten Kampar bisa memberikan penyuluhan hukum di setiap Kecamatan, dan memberikan buku saku kepada pemerintahan desa, buku saku tersebut berisi pedoman dalam membentuk peraturan desa.

b. Pengawasan Pembentukan Peraturan Desa yang Optimal dan Efektif Oleh Bagian Hukum Pemerintahan Kabupaten Kampar

Bentuk pengawasan yang bersifat preventif harus mulai dioptimalkan oleh Bagian Hukum Sekretariat Daerah. Pengawasan Preventif artinya pengawasan ini dilakukan diawal dan sifatnya mencegah, memiliki fungsi agar mencegah adanya kekurangan dan kekeliruan yang terjadi dalam pembentukan Peraturan Desa. Maka dari itu yang bisa direkomendasikan oleh peneliti agar pengawasan yang dilakukan bisa optimal dan efektif, dalam hal ini untuk kedepannya Bagian hukum harus melakukan:

1) Pengawasan Preventif

Peneliti merekomendasikan kepada Bagian Hukum Sekretariat Daerah untuk :

a. Menerbitkan Buku Pedoman/Panduan Khusus

b. Progam Konsultasi Hukum

c. Pembinaan berupa pelatihan Penyusunan Peraturan Desa

2) Pengawasan Represif

Peneliti merekomendasikan untuk menjalankan tugas dari Bagian Hukum yang telah tercantum di dalam Perbup Tupoksi Sekretariat Daerah Pasal 70 yakni “melakukan pembinaan dan pengawasan penyusunan produk hukum desa”. Peneliti memberikan rekomendasi untuk membentuk Tim Monitoring dan Pendampingan untuk mendampingi dan memonitoring mulai dari penyusunan Peraturan Desa sampai dengan pengundangan. 
Adapun Proses Penyusunan dan

\section{Penutup}

\section{Kesimpulan}

Hubungan Kewenangan Kepala Desa Dengan Badan Permusyawaratan Desa (BPD) Dalam Pembentukan Peraturan Desa Aursati dapat disimpulkan bahwa, Pola hubungan Kewanangan antara Badan Permusyawaratan Desa (BPD) dan Kepala Desa adalah dalam bentuk hubungan kemitraan, konsultasi, dan koordinasi. Pertama, Bentuk pola hubungan kemitraan yaitu Kepala Desa dan Badan permusyawaratan Desa membahas dan menyepakati peraturan Desa, Kepala Desa menyerahkan laporan penyelenggaraan pemerintahan desa secara tertulis kepada BPD, Kepala Desa mengajukan rancangan APBD dan memusyawarahkannya bersama BPD, dan Kepala desa dan BPD . Kedua, Pola hubungan konsultasi Kepala Desa dalam pembentukan lembaga Kemasyarakatan Desa, pengangkatan perangkat atau staf desa, kegiatan atau peringatan hari-hari besar nasional atau keagamaan serta hal-hal lainnya yang menyangkut pemerintahan desa. Ketiga, Koordinasi antara badan Permusyawaratan Desa (BPD) dan Kepala Desa bisa dilihat dalam pelaksanaan program yang ada di desa baik program dari pemerintah atau pun program yang menjadi hak Desa itu sendiri.
Pembentukan Peraturan Desa Aursati.

Dalam penyusunan peraturan desa yang dilakukan oleh Badan Permusyawaratan Desa (BPD) dengan Kepala Desa Aursati, proses penyusunannya menggunakan mekanisme yang benar dan semua tahap dilalui dengan baik. Pertama, persiapan penyusunan Peraturan Desa, yang terdiri dari tahap perencanaan dan persiapan dalam pembentukan peraturan desa. Kedua, proses penyusunan Peraturan Desa, melalui tahap proses perumusan pembahasan dan teknik penyusunan peraturan desa serta pengesahan, pengundangan dan penyebarluasan peraturan desa. Secara normatif pembentukan perdes di Aursati telah sesuai, namun berdasarkan indikator penilaian terhadap Perdes di Aursati belum sepenuhnya mengakomodir asas-asas pembentukan Peraturan Perundangundangan demikian juga dengan ketentuan Kerangka Pembuatan Peraturan Perundang-undangan belum sepenuhnya diterapkan. Hal ini disebabkan oleh: Pertama, Pemerintah desa kurang paham terhadap Peraturan Pemerintah Nomor 72 Tahun 2005 tentang Desa. Hal ini diakibatkan pula oleh kurangnya sosialisasi dari pemerintah daerah. Kedua, Kinerja anggota BPD Desa Aursati kurang maksimal. Ketiga, Kesadaran masyarakat terhadap peraturan desa. Keempat, 
Kemampuan kinerja pemerintahan desa dalam menyampaikan peraturan desa kurang efektif. Dengan demikian dibutuhkan strategi untuk mewujudkan Perdes yang bukan saja sesuai dengan asas-asas pembentukan Peraturan Perundang-undangan maupun ketentuan Kerangka Pembuatan Peraturan Perundang-undangan akan tetapi mewujudkan Perdes yang berkualitas diantaranya melalui peningkatan pengetahuan hukum melalui pengawasan pembentukan peraturan desa yang optimal dan efektif oleh bagian hukum pemerintahan Kabupaten Kampar, adanya perencanaan yang matang dalam membuat dan rancangan peraturan desa.

\section{Daftar Pustaka}

Dirgantara Dani Putra, Hubungan dan Peran Serta Badan Permusyawaratan Desa (BPD) dan Pemerintahan Desa Dalam Penyelenggaraan Pemerintahan Desa, Skripsi Universitas Sebelas Maret Surakarta, Solo, 2009.

E.B. Sitorus, dkk, Naskah Akademik Rancangan Undang-Undang tentang
Pemerintahan Desa, DEPDAGRI, Jakarta, 2007.

Kushandajani, Otonomi Desa Berbasis Modal Sosial Dalam Perspektif Socio Legal, (Jurusan Ilmu Pemerintahan Fisip UNDIP, Semarang, 2008).

M. Firmanhadi, Hubungan Fungsional Antara Pemerintah Desa dengan BPD dalam Menjalankan Pelaksanaan Pemerintahan Desa Berdasarkan Undang-Undang Nomor 32 Tahun 2004 tentang Pemerintahan Daerah, Jurnal Ilmiah Fakultas Hukum Universitas Mataram, 2013.

Maria Eni Surasih, Pemerintah Desa dan implementasinya, (Jakarta: Erlangga, 2002)

Stewar Awaeh, Johannis E. Kaawoan, dan Josef Kairupan, Peranan Badan Permusyawaratan Desa (BPD) Dalam Penyelenggaraan Pengawasan Pemerintahan (Studi di Desa Sereh 1 Kecamatan Lirung Kabupaten Talaud), Jurnal Eksekutif, Vol 1, No 1 (2017).

Undang-Undang Republik Indonesia Nomor 6 Tahun 2014 Tentang Desa

Wasistiono, Sadu. 2006. Prospek Pengembangan Desa. CV. Bandung. Fokusmedia. 